\title{
Conditioning the position of the President of the Republic of Poland in the country's system of governance during its 1989-1997 transformation period
}

Keywords: President, systemic transformation, conditioning of position in the system of governance

Abstract: This article seeks to identify and detail the most important determinants that shaped the position of Poland's President in the system of governance during the country's period of transformation extending from 1989 through to 1997. The conditioning presented determined the position of the office of President by reference to four legal instruments, i.e. the new proposal of April 1989, the 1990 Act on universal suffrage in electing the President of the Republic of Poland (Ustawa o powszechnych wyborach prezydenta RP), the so-called "Small Constitution" of 1992, and the (still-binding) 1997 Constitution of the Republic of Poland. It is claimed here that this conditioning underpinning the establishment of the post of President within Poland's system of governance, on the basis of these different instruments of law, remained similar (sometimes in fact identical), with the overriding, repeated determinant being the political situation at the given time.

\section{Introduction}

The institution of President as reinstated within Poland's constitutional order in 1989 was the subject of ongoing evolution in successive instruments of law from the time of onset of the country's transition

* ORCID ID: https://orcid.org/0000-0003-2944-5073; professor at the Faculty of Political Science and Journalism, Marii Curie-Skłodowska University in Lublin. Email: bozena.dziemidok-olszewska@poczta.umcs.lublin.pl. 
through to the enactment of the Constitution in 1997. As was noted above, the period in question saw four fundamental changes enacted - by way of the new proposal from April 1989, the 1990 Act laying down rules for Presidential elections, the Mała Konstytucja (Small Constitution) of 1992 and the true Constitution for Poland arrived at and passed in 1997.

Against that background, this article seeks to detail the key determinants helping shape the position of President within Poland's system of governance during the 1989-1997 transformation period. In that connection, the research questions formulated can be summarised as: which (or which kinds of) factors determined the creating of the legislative solutions involved? which factors were involved repeatedly? And which factors can be seen as most important?

In response to those questions, this publication has assumed that the enactment of each legal instrument referred to has been the result of a series of mutually influential and interrelated factors that include a certain number that have truly been to the fore. Three research hypotheses could then be advanced. The first of these holds that the conditioning behind the making of the four aforementioned legal instruments of key importance in regulating the position of the President within Poland's system of governance were similar or even identical. The second (leading) hypothesis was that the key determinant of the above, arising each time, was the political situation of that given moment. That leaves a third hypothesis which assumed that the institution of President of Poland was constructed and has evolved in line with no defined vision or model, with the result being a hybrid (or mongrel) shape conferred upon that office. The method used to research these contentions further have ben synthesis.

\section{The new proposal of April 1989}

The reinstatement of the office of President was achieved by virtue of an amended version of the Constitution of the Polish People's Republic, enacted on April $7^{\text {th }}$ 1989. This offered formal and legal sanctioning of the agreement concluded successfully by the parties around the Round Table (Okragty Stót). The negotiations involved here ${ }^{1}$ had been commenced with, given what had been dubbed the dimensions of

1 For more on the Round Table Talks, see K. Trembicka, Okragły Stót w Polsce. Studium o porozumieniu politycznym, Lublin 2003. 
"the socio-economic crisis" Poland faced, and the degree to which "the system" had become eroded ${ }^{2}$. Their result was for a package of political, social and economic reforms to be devised - sufficient for part of the Opposition in Poland to be co-opted into participation in so-called non-confrontational elections to the Sejm. This was also taken to denote joint responsibility/accountability for ensuring that the country might emerge from the aforementioned crisis $^{3}$.

A key element of the reform of the Polish state - and a main proposal put forward by the government side - was that the institution of President should now be brought in, with a view to its guaranteeing their retention of some power. It was against this background that the proposal for the office of President they came up with was underpinned by the idea of this new Head of State being an arbiter, and thus being equipped with the entitlements needed to pursue an arbitration function (in many cases taking on those previously at the disposal of the communist-era Council of State). However, for this and other reasons, the construct that was the arising office in question was not a cohesive or logical one - being more in the nature of a rough outline of an institution enjoying a wide range of competences.

From the time the negotiations began, the Opposition ("Solidarity") side lived up to its name by expressing its implacable opposition to the government proposal in general, and this one in particular, which they regarded - and called - dictatorship and a coup-like means to the end that was republican-type government ${ }^{4}$. At the same time, those involved made it quite clear that this mistrust of the institution of President would be quelled were this person to be elected directly by universal suffrage, or else in the wider context of free elections to the Sejm. Such a stance offered an indication of the price Solidarność as a party to the Talks might be imposing for any recognition of the controversial new institution.

The negotiations thus entered a period of impasse that Aleksander Kwaśniewski (younger Party figure and future President of Poland) broke through when he proposed free elections to the Senat in exchange for Opposition consent to the establishment of the institution of "strong President" ${ }^{2}$. An agreement was then concluded, even as the topic of

2 R. Mojak, Instytucja Prezydenta RP w okresie przekształceń ustrojowych 1989-1992, Warsaw 1994, p. 75.

$3 \quad$ R. Mojak, Instytucja Prezydenta RP..., p. 63.

4 See J. Ciapała, Prezydent w systemie ustrojowym Polski (1989-1997), Warsaw 1999, p. 18.

5 K. Leszczyńska, Senat Rzeczypospolitej Polskiej w latach 1989-2011, Lublin 2015, p. 65. 
President served as the subject of long debate (and as a bargaining chip vis-à-vis other intractable issues) through to the very end of the Round Table deliberations on April $3^{\text {rd }} 1989$.

But regarding the matter in question here as a priority, the government side sought to equip the President with a broad remit. For its part, the Opposition was bent on frustrating that goal, its intention wherever possible being to diminish the status of the office of President, while ensuring that the position of the Senat was enhanced. In practice, the issues proving most hard to agree on were Presidential Decrees, the right to dissolve the Sejm, the legislative veto and the size of any majority in the Sejm that would be necessary to overturn such a veto from the President and the Senat.

Thus the role of the President was ultimately as designated via the Round Table Talks, so it was in this context and against that background that we find - in the agreement entitled Stanowisko $w$ sprawie reform politycznych ("the Standpoint in the matter of political reforms") - wording as follows: Ustanowienie instytucji Prezydenta uzasadnione zostało potrzeba utrzymania stabilności państwa oraz podejmowania decyzji $w$ przypadku zablokowania prac $w$ Sejmie $i$ Senacie lub przewlektego kryzysu rzadowego ${ }^{6}$ ["The decision to establish the institution of President has been justified by the need to maintain the stability of the state and to ensure decision-making, should the work of the Sejm and Senat be blocked, or should there be a protracted government crisis"]. A Presidency thus came in, on account of its being an institution that could both guarantee and ensure the evolutionary regulation of Poland's "makeover" in the direction of a democratic system ${ }^{7}$.

The office of President was to take the place in the state of the Polish United Workers' Party PZPR - with its hitherto-leading role, though in fact serving as an "ultimate guarantor of PZPR's ongoing control over

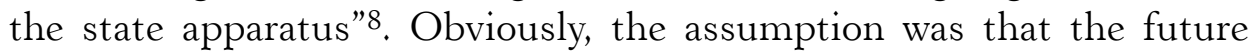
President would originate within Party circles, making it possible for the government party to the Talks to exert an influence on the process of political transformation. The President was thus perceived as putting

6 „Porozumienia okragtego stotu”, Warsaw 6 February-5 April 1989, Wyd. NSZZ „S” Region Warmińsko-Mazurski 1989, p. 10.

7 See inter alia R. Glajcar, Demokratyczny reżim polityczny. Relacje między legislatywa i egzekutywa w III Rzeczypospolitej, Katowice 2015, p. 180; R. Mojak, Instytucja prezydenta RP..., pp. 81-82.

8 L. Garlicki, Klasyczne modele ustrojowe a koncepcja polskiej prezydentury, [in:] Instytucja prezydenta we wspótczesnym świecie. Materiaty na konferencje Warszawa - Senat RP, 22-23 February 1993, Warsaw 1993, p. 67. 
some kind of brake on things, and preventing any over-radical undertakings on the part of Parliament, given that the Opposition would now be finding a place for itself there. A further important role for the President was to safeguard and ensure ongoing respect for constitutional principles as regards foreign policy, with this naturally to entail ongoing preference for the ties existing with other countries of the Eastern Bloc.

As R. Mojak noted, the hybrid system of governance ushered in by the April amendment linked elements extracted from the Soviet, parliamentary and presidential systems ${ }^{9}$. The office of President was being constructed in such a way that certain threads relating to the Head of State in the communist era were present in it (given that the President would be taking on many of the entitlements of the previous Council of State), along with those of a parliamentary Head of State and presidentialism (with certain forms of wording in the April amendment recalling France's 1958 Constitution). The legal nature of the office as somehow undefined was only furthered by the way that in no provision of the Constitution was the President termed an organ of authority or state administration, as were - say - the Sejm of the Republic of Poland or the Government.

It is clear from the above that the 1989 reactivation of the office of President was determined, not in line with theoretical considerations or Polish governance traditions, but via political premises and the views held by the then governing elite ${ }^{10}$. As W. Sokolewicz rightly observed: doraźny, polityczny efekt górował wyraźnie nad racjami doktrynalnymi, czy też troska o chociażby niewielkie przybliżenie do jakiegoś idealnego „docelowego” modelu ustroju państwa ${ }^{11}$ ["an ad hoc political impact had clearly prevailed over doctrinal rectitude, or any care to achieve even a limited approximation to some ideal or 'target' model when it came to a state system of governance"]. The reinstatement of the office of President thus boiled down to that office being used instrumentally - and in relation to economic conditions - with a view to ad hoc political objectives being pursued ${ }^{12}$.

Political considerations also decided upon the shape of the office of President as adopted, as well as its outfitting with a broad remit in respect of the enactment of general or unclear constitutional formula-

9 R. Mojak, Instytucja Prezydenta Rzeczypospolitej Polskiej w systemie ustrojowym państwa w okresie transformacji ustrojowej w latach 1989-1991, [in:] A. Pułło (ed.), Zagadnienia wspótczesnego prawa konstytucyjnego, Gdańsk 1993, p. 89.

10 B. Dziemidok-Olszewska, Instytucja prezydenta w państwach Europy Środkowo-Wschodniej, Lublin 2003, p. 23; R. Glajcar, Demokratyczny reżim..., p. 181.

11 W. Sokolewicz, Konstytucja wobec ewolucyjnej zmiany ustroju: od dyktatury proletariatu do demokracji parlamentarnej, Studia Konstytucyjne, vol. VIII, Warsaw 1990, pp. 32-33.

12 R. Mojak, Instytucja Prezydenta..., p. 88; R. Mojak, Instytucja Prezydenta RP..., p. 64. 
tions, with this serving to make rather free interpretations possible. The model ushered in for the Presidency represented a new concept, and thus did not reflect existing systemic models; and nor was it a continuation of Polish constitutional traditions ${ }^{13}$. It was in fact shaped under the influence of the political situation's ongoing development, and was "tailored" to fit the candidate foreseen as holding the office of President (i.e. General Wojciech Jaruzelski).

\section{Presidential elections by universal suffrage -1990}

A further reform when it came to the office of President was Polish history's first introduction of universal, direct Presidential Elections. September 27th 1990 brought the enactment of the Act amending the Constitution of the Republic of Poland, as well the Act on the Election of the President of the Republic of Poland. The reason for these changes was the way in which most political groupings had spoken up for the curtailment of the term in office of the aforementioned President Jaruzelski, and for the consequent legitimisation of President and Presidency thanks to a direct popular mandate. This would at the same time bring the means of election in line with competences conferred earlier ${ }^{14}$.

However, to cut a long story short - also with some simplification the establishment of direct elections to the Presidency might be viewed as a change made under pressure imposed by Lech Wałęsa himself, as well as the Porozumienie Centrum formation acting in support of him ${ }^{15}$. Indeed, the result of the election held on December $9^{\text {th }} 1990$ was for Wałęsa to be elected President of the Republic of Poland.

\section{The Small Constitution of 1992}

October $17^{\text {th }} 1992$ saw the adoption of a Constitutional Act shaping the mutual relations between Poland's legislature and executive as well as local and regional governance, which went by the semi-official title

\footnotetext{
13 D. Górecki, Wplyw polskich tradycji ustrojowych na wspótczesne rozwiąania konstytucyjne, [in:] M. Domagała (ed.), Konstytucyjne systemy rządów, Warsaw 1997, p. 19.

14 T. Słomka, Prezydent Rzeczypospolitej po 1989 roku. Ujęcie porównawcze, Warsaw 2005, p. 104; T. Mołdawa, Ewolucja konstytucyjna Polski w latach 1989-1992, [in:] E. Zieliński (ed.), Przeobrażenia ustrojowe w Polsce, Warsaw 1993, p. 80.

15 Por. R. Glajcar, Demokratyczny reżim..., p. 226 et seq.
} 
of the Small Constitution. This was by definition a legal instrument of a temporary and fragmentary nature, adopted - as its Introduction noted $-w$ celu usprawnienia działalności naczelnych władz państwa, do czasu uchwalenia nowej Konstytucji Rzeczypospolitej Polskiej16 ["to streamline the activity of leading authorities of the state until such time as a new Constitution of the Republic of Poland is enacted"].

Basically speaking, the Small Constitution brought in no new concept where the institution of President of Poland was concerned. Indeed, as it was being prepared, there was no expression of doubt manifested when it came to the justification for the office of President to exist, with no variants for any entirely new solutions being looked at or considered. The starting point for those framing the Small Constitution was thus to keep the existing model from 1989 in place, while taking account of the amendments brought in subsequently (mainly as regards the President being elected by universal suffrage). There was thus a confinement here to partial - though at times significant - modifications of the regulations in place up to that time ${ }^{17}$.

The lack of any clear vision for the office and acceptance of earlier solutions reflected the way in which the Small Constitution arose in a period of bitter political dispute between Parliament and President Wałęsa. The Sejm's weakness resulting from political divisions combined with the strong personality of Wałęsa to obstruct any curtailment of the post of President. In turn, Wałęsa's own proposal that Presidential powers should be extended failed to gain any wider acceptance with the public. In consequence, the Small Constitution was - as it basically speaking had to be - a result of compromise between advocates of parliamentarianism and those in favour of a strong position for the President. The price paid for this compromise was for this instrument to be deprived of its internal cohesion, with inconsistent legal constructs present, and even legislative deficiencies in the text ${ }^{18}$.

The Small Constitution thus provided for an original system of governance proving hard to identify unambiguously, and linking solutions of both a parliamentary and a semi-presidential system (not least

16 Ustawa Konstytucyjna z dnia 17 października 1992 r. o wzajemnych stosunkach między władzą ustawodawczą i wykonawczą Rzeczypospolitej Polskiej oraz o samorządzie terytorialnym, Dz.U. 1992 Nr 84, poz. 426.

17 M. Domagała, Instytucja prezydenta Rzeczypospolitej Polskiej w świetle małej konstytucji z 17 X 1992 r., [in:] Instytucja prezydenta we wspótczesnym świecie. Materiaty na konferencje Warsaw - Senat RP, 22-23 February 1993, Warsaw 1993, p. 95.

18 W. Sokolewicz, Rozdzielone, lecz czy równe? Legislatywa i egzekutywa w Małej Konstytucji 1992 roku, «Przegląd Sejmowy» 1993, no. 1, p. 23. 
direct elections of the President via universal suffrage). The government system it ushered in may be defined, after W. Sokolewicz, as parlamentaryzmem zracjonalizowanym ze szczególnie zaakcentowana rola wybieranego $w$ powszechnych wyborach prezydenta 19 ("rationalised parliamentarianism with a particularly emphasised role for a popularly-elected President”).

Thus was the office of President of Poland placed within a more-distinct constitutional framework. However, a cohesive concept for the Presidency was lacking, with different regulatory solutions originating in a variety of different models of governance. Moreover, there was a little precision or clarity to much of the wording, allowing for diverse interpretations and means of application. This all led to a real-life extension of the President's remit. In line with the logic of the aforesaid "rationalised parliamentarianism", the role of the President would seem to have been limited wherever and whenever a stable parliamentary majority came to be present in the Sejm. However, "in practice things emerged as more complicated - and the problem of the Presidency greater - than would have seemed to be the case in line with the letter of the Small Constitution, with matters continuing to go unresolved through to the time of President Lech Wałęsa's losing of the election in late 1995" 20. The causes of that state of affairs need to be looked for, not only in the Constitutional solutions arrived at, but also in the lack of political traditions and customs, as well as a lack of political good behaviour among the ruling elites.

The Small Constitution both regulated and shaped the process of systemic transformation through the years 1992-1997, representing a further stage in the evolution of Polish constitutionalism. The significance of that lay first and foremost in the way that the adopted systemic solutions included within it, as well as the practice following on from them, did too much prejudging of the shapes of different institutions and governance systems under the Constitution of the Republic of Poland. Even as numerous decisions and solutions arrived at in the Small Constitution (not least those relating to the position of the President within the governance system, art. 28) did come to be seen as right and worth repeating, others (such as "Presidential departments", art. 32, 34) were viewed as negative examples and solutions, needing to be avoided next time round 21 .

19 Ibidem.

20 L. Garlicki, Polskie prawo konstytucyjne. Zarys wykładu, Warsaw 1998, p. 25.

21 See P. Winczorek, Uwarunkowania prac nad nowa Konstytucja Rzeczypospolitej Polskiej, «Państwo i Prawo» 1997, no. 11-12, p. 16. 


\section{The 1997 Constitution of the Republic of Poland}

The work on a new Constitution that had been pursued since 1989 bore fruit in the 1991 appearance of drafts from both the Sejm Deputies and the Senators. The marked disparities between these, and the questioning of the legitimacy of the "contract" Sejm when it came to enacting a new Constitution both ensured that neither draft went on to become a formal legislative initiative. However, a constitutional act on the means of preparing and enacting a Constitution of the Republic of Poland was passed on April $23^{\text {rd }}$ 1992, with this laying down a detailed procedure in line with which the basic law might be enacted.

The National Assembly convened on April $2^{\text {nd }} 1997$ - to enact the Constitution of the Republic of Poland 22 , while its adoption by the nation took place in the Referendum of May $25^{\text {th }}$ that same year. The Referendum achieved a turnout of $42.86 \%$ of those entitled to vote, with $53.45 \%$ of participants coming out in favour of the Constitution being adopted ${ }^{23}$. These results were very much a reflection of a call from the Opposition outside Parliament for the proposed Constitution to be rejected.

As work continued to make ready and enact the new Constitution, it gave rise to questions needing to be seen as having a direct influence on how the constitutional position of the President was shaped. First there was the concept for the office of President set out in the drafts for the Constitution laid before the National Assembly, and then there was the debate engaged in within the Constitutional Committee of the National Assembly, which led to the ultimate construct of the institution of President as it was put into effect.

While the Constitutional Act of 1992 conferred the right to come up with new Constitutional proposals upon the President, or else a group of 56 members of the National Assembly, the new proposal dated April 22 $2^{\text {nd }} 1994$ extended that right to include a group of at least 500,000 citizens. It also made it possible to debate and consider drafts that had been put forward during a previous term. These regulations reflected an opinion that the Sejm elected in September 1993 had not

22 Konstytucja Rzeczypospolitej Polskiej z dnia 2 kwietnia 1997 r. uchwalona przez Zgromadzenie Narodowe w dniu 2 kwietnia 1997 r., przyjęta przez Naród w referendum konstytucyjnym w dniu 25 maja 1997 r., podpisana przez Prezydenta Rzeczypospolitej Polskiej w dniu 16 lipca 1997 r., Dz.U. 1997 Nr 78, poz. 483.

23 Obwieszczenie Państwowej Komisji Wyborczej z dnia 26 maja 1997 r. o wynikach głosowania i wyniku referendum konstytucyjnego przeprowadzonego w dniu 25 maja 1997 r., Dz.U. 1997 Nr 54, poz. 353. 
been especially representative, with the Opposition only enjoying limited possibilities to put forward Bills and other forms of draft legislation.

Ultimately, the National Assembly was to receive seven draft versions of a Constitution, offering a variety of different visions for the Polish state and its system of governance. In the course of work on the Constitution for Poland, account was taken of legal solutions deriving from various different submitted drafts, with the resultant Constitution not therefore representing a true reflection of any particular project, and not based clearly on any one of them ${ }^{24}$. The different versions made reference to the governance system shaped previously (above all to the Small Constitution), and anticipated for the President a similar scope of entitlements, albeit either limited or expanded. Thus it can be stressed that none of the drafts put forward actually foresaw a reduced standing for the Presidency - to the point where this became a purely representative or figurehead role. Indeed, a strong position modelled on the French Presidency was advocated in one of the drafts, i.e. the one submitted by Wałęsa himself. Nevertheless, all of the proposed versions were in line with each other in the matter of universal, direct elections, with this being regulated in the same way as in the Small Constitution.

It was particular parties that were able to exert the most major influence on the shaped assumed by both the institution of President and other aspects provided for by virtue of constitutional provisions. Through to the present, it is widely felt that the 1997 Constitution of the Republic of Poland remaining in force is the work of the four parties gaining representation in the Parliament elected in 1993 - i.e. Sojusz Lewicy Demokratycznej, Polskie Stronnictwo Ludowe, Unia Wolności and Unia Pracy ${ }^{25}$. At the National Assembly's Constitutional Committee, these (in essence centre-left or left-of-centre) parties formed a constitutional coalition allowing them to devise and institute new regulations ${ }^{26}$. Moreover, as W. Tomaszewski wisely noted, the compromise arrived at by that constitutional coalition in the years 1993-1997 "was based on political exchange, and on the achievement of solutions regarding the Constitution that it would prove possible for the greatest number of political groupings to accept". [...] "The agreement arrived at was [...]

24 W. Skrzydło, Ustrój polityczny RP w świetle Konstytucji z 1997 r., Kraków 1998, p. 55.

25 T. Słomka, Stan demokracji konstytucyjnej $w$ Polsce na tle modelu transformacji systemowej, [in:] T. Słomka (ed.), Demokracja konstytucyjna w Polsce, Warsaw 2019, p. 32.

26 T. Słomka, Między dwiema konstytucjami: kilka uwag o specyfice polskiej ciagtości i zmiany systemowej, [in:] A. Materska-Sosnowska, T. Słomka (eds.), Konstytucje polskie z 1952 i 1997 roku: tradycja, instytucje, praktyka ustrojowa, Warsaw 2015, p. 18. 
voluntary, the result of give and take on all sides, motivated by the desire to arrive at the common objective that enactment of the new Constitution denoted. But of course that meant that that Constitution was the result of political compromise taking in the parliamentary majority" 27 . It also needs stressing how the compromise and understanding taken up reflected a desire for the Constitution to gain the acceptance of as many citizens and parts of the political elite as possible.

The debate surrounding the institution of President that took place in the context of the National Assembly's Constitutional Committee can be described as a calm and temperate one. The work on the model for the Presidency was something in the nature of an arranging or ordering of the one that had been in place hitherto. There was a "given" from the very outset that the post of President needed weakening, even as it might not be deprived of is arbiter function. However, more-precise regulation was accepted, with the aim of this being to prevent conflicts arising out of legal loopholes.

As the Constitutional Committee was doing its work, a more serious dilemma of a political and systemic nature related to the way in which the President might be elected. In this matter, three proposals were put forward: i) that the President would be chosen by and from within the ranks of the National Assembly (P. Ikonowicz), ii) that there would be direct election by universal suffrage, with a preference vote and a single round (W. Cimoszewicz), and iii) that there would be the same kind of direct election but with two rounds of voting. Those in favour of continuing with the previous means of electing the President resorted to two main arguments: the fact that the system was already in force and was becoming an element of political practice, and the fact that it had gained the wide acceptance of the public.

Ultimately, there was indeed retention of the principle of direct universal elections to the Presidency and with two rounds, as had been brought in back in 1990. However, the decision here did not arise from systemic premises, and was not the consequence of any adoption of a defined model for the state. Rather, it was in the main motivated politically, with the approval of society for the direct aspect, and with the fact that they had become accustomed to this way of doing things. Any introduction of indirect elections was seen as a step backwards from the most-democratic available procedure that direct universal elections

27 W. Tomaszewski, Kompromis polityczny w procesie stanowienia Konstytucji Rzeczypospolitej z kwietnia 1997 roku, Pułtusk 2007, pp. 412-413. 
represented, all the more so as the public's political participation and involvement would be viewed as subject to confinement in this way ${ }^{28}$.

In sum, the model for the Presidency decided upon may be seen as influenced by factors including a desire to achieve broad public consensus, concepts advanced by four political parties and the compromise they arrived at, the multiplication of regulations already made, the weakening of the office to the benefit of the parliamentary system and experiences with the Presidency as practised by Lech Wałęsa.

\section{Conclusions}

In the course of the 1989-1997 process by which the Presidency of the Republic of Poland was shaped, it is possible to distinguish two phases, i.e. the strengthening of 1989-1990 and the weakening of 1992-1997. The 1989 establishment of a strong Presidency reflected the political situation, while the imposition of limitations came along as the system of governance in the country underwent a certain rationalisation and ordering, with models for a parliamentary system of government adopted.

The evolution of the position of President (and constitutional system) was in fact determined in line with many and varied premises, if ones that may still be arranged into a sequence of factors often identical in nature, even as they played more or less significant roles in the course of the different stages.

What conditioned the selection of system-of-governance solutions for the institution of President in the course of the systemic transformation were: the political situation of the given moment, account taken of solutions already introduced, the interests and concepts crucial to different political parties, the standards met by Western democracies, and the various personalities of different national leaders.

A universally-present form of conditioning of the position of President in Poland came in the situational context, and in the pursuit of concrete, but at times ad hoc political objectives. The evolution of the country's system of governance was in fact seen to entail "pragmatic adjustments of Constitutional provisions to the needs of the time and

28 Cf. A. Antoszewski, Konstytucja w świetle refleksji politologicznej, [in:] K. B. Jankowski (ed.), Nowa Konstytucja RP: wartość, jednostka, instytucje, Torun 1995, pp. 41-42. See also R. Glajcar, Dwadzieścia pięć lat powszechnych wyborów prezydenckich w Polsce. Potrzeba rewizji?, «Studia Politologiczne» 2016, vol. 42. 
to political and systemic processes" 29 . Back in 1989, the institution of Polish President was put together by way of bargaining, with the Polish United Workers' Party seeking to retain its control over the state system, while the Opposition side wanted to see a strong Senat put in place as upper house. The 1990 ushering-in of Presidential Elections entailing universal suffrage and a popular vote reflected a desire upon the part of Lech Wałęsa to take up the office. Further instruments emerged by way of negotiation, as well as rationalisation by weakening, in line with the political atmosphere and circumstances of the given time, and indeed the strengths of different political parties.

The ultimate construct that the office of President came to be saw respect extended (under pressure from different political forces) to a solution already introduced previously. That is to say there was proper recognition of what was already a fait accompli ${ }^{30}$. The entitlements enjoyed by the President of Poland under the April 1989 provisions reflected ongoing inviolability of alliances within the communist camp. However, as the causes motivating and underpinning that state of affairs ceased to apply, they took on a life of their own and reappeared as Presidential aspirations to formulate entitlements of a similar kind ${ }^{31}$.

A further "done deal" taken account of subsequently by those involved in the successive constitutionally-inspired regulations concerned the universal direct election of the Presidency introduced in 1990. During the process by which Poland's Constitution was framed and put in place it was only the detailed solutions that changed, while the general position of the office within the system of governance - and as regards its remit - failed to alter in any more profound way.

As the office of President evolved, conditioning resided in political parties' pursuit of their goals and concepts. "The Party" (PZPR) backed a strong Presidency because it felt that this would allow it to keep a firm eye on changes introduced, as well as society overall. Equally, as work on a Constitution for Poland was ongoing, a main role was played by the drafts concerning the system of governance - and politics - that four political parties showing a preference for liberal democracy were able to come up with.

29 R. Mojak, Transformacja ustroju politycznego w latach 1989-1997, [in:] W. Skrzydło (ed.), Polskie prawo konstytucyjne, Lublin 2002, pp. 80-81.

30 Por. M. Kruk, Parlament - prezydent - rzad: wybór modelu rządów, [in:] Prawo w okresie przemian ustrojowych $w$ Polsce, Warsaw 1995, p. 26.

31 B. Dziemidok-Olszewska, Instytucja prezydenta..., p. 85. 
A further influencing factor entailed state heritage, tradition and experience (be that negative or positive), including the way in which earlier Constitutions had construed the office of President. Negative models in this sense were provided by the April (1935) Constitution, as well as the system installed under "Real Socialism"; while a positive one was the March (1921) Constitution. Beyond that, there was a tangible desire to make reference to Western models and existing democratic standards vis-à-vis systemic solutions, as well as a striving to ensure that one or other defined model for systems of government was taken up.

A major premise underpinning this institution's further modelling and construction entailed the personality and style of leadership characteristic for the then incumbent President Lech Wałęsa. This is to say that it was in fact negative experiences with Wałęsa's Presidency, and a reasonable assumption that he might (go on to) win the 1995 Presidential Elections, that were to influence the course of work in Parliament regarding a new Polish Constitution. In the event, when it (in December 1995) "emerged that the new President was going to be Aleksander Kwaśniewski, while parliamentary elections might be lost by the coalition formed between the Democratic Left Alliance and Polish Peasants' Party (SLD and PSL), it was already too late for any radical change in the concept assumed for the Presidency under the new Constitution" 32.

Desirable conditioning would be the adoption of a defined model for a system of government, with the Presidency then shaped in line with the model taken on, in accordance with rules or principles under the governance system. However, Poland's constitutional makeovers were not of this kind, hence there was no implementation of any clear or targeted vision for the system of governance domestically. They can be said to have resulted from socio-political transformations being made at the time, but they are also readily and reasonably dubbed: "a rapid reaction to shortfalls making their presence felt, along with perceived threats of a systemic nature" 33 .

\section{Bibliography}

Antoszewski A., Konstytucja w świetle refleksji politologicznej, [in:] K. B. Jankowski (ed.), Nowa Konstytucja RP: wartość, jednostka, instytucje, Torun 1995.

Ciapała J., Prezydent w systemie ustrojowym Polski (1989-1997), Warsaw 1999.

32 L. Garlicki, Polskie prawo konstytucyjne..., p. 216.

33 T. Mołdawa, Ewolucja konstytucyjna..., p. 83. 
Domagała M., Instytucja prezydenta Rzeczypospolitej Polskiej w świetle małej konstytucji z 17 X 1992 r., [in:] Instytucja prezydenta we wspótczesnym świecie. Materiały na konferencje Warsaw - Senat RP, 22-23 February 1993, Warsaw 1993.

Dziemidok-Olszewska B., Instytucja prezydenta w państwach Europy Środkowo-Wschodniej, Lublin 2003.

Garlicki L., Klasyczne modele ustrojowe a koncepcja polskiej prezydentury, [in:] Instytucja prezydenta we wspótczesnym świecie. Materiały na konferencje Warsaw - Senat RP, 22-23 lutego 1993, Warsaw 1993.

Garlicki L., Polskie prawo konstytucyjne. Zarys wykładu, Warsaw 1998.

Glajcar R., Demokratyczny reżim polityczny. Relacje między legislatywa i egzekutywa w III Rzeczypospolitej, Katowice 2015.

Glajcar R., Dwadzieścia pięć lat powszechnych wyborów prezydenckich w Polsce. Potrzeba rewizji?, «Studia Politologiczne» 2016, vol. 42.

Górecki D., Wptyw polskich tradycji ustrojowych na wspótczesne rozwiąania konstytucyjne, [in:] M. Domagała (ed.), Konstytucyjne systemy rząów, Warsaw 1997.

Kruk M., Parlament - prezydent - rzad: wybór modelu rząów, [in:] Prawo w okresie przemian ustrojowych $w$ Polsce, Warsaw 1995.

Leszczyńska K., Senat Rzeczypospolitej Polskiej w latach 1989-2011, Lublin 2015.

Mojak R., Instytucja Prezydenta RP w okresie przekształceń ustrojowych 1989-1992, Warsaw 1994.

Mojak R., Instytucja Prezydenta Rzeczypospolitej Polskiej $w$ systemie ustrojowym państwa w okresie transformacji ustrojowej $w$ latach 1989-1991, [in:] Zagadnienia wspótczesnego prawa konstytucyjnego, A. Pułło (ed.), Gdańsk 1993.

Mojak R., Transformacja ustroju politycznego w latach 1989-1997, [in:] W. Skrzydło (ed.), Polskie prawo konstytucyjne, Lublin 2002.

Mołdawa T., Ewolucja konstytucyjna Polski w latach 1989-1992, [in:] E. Zieliński (ed.), Przeobrażenia ustrojowe $w$ Polsce, Warsaw 1993.

„Porozumienia okragłego stotu”, Warsaw 6 February-5 April 1989 r., Wyd. NSZZ „S” Region Warmińsko-Mazurski 1989.

Skrzydło W., Ustrój polityczny RP w świetle Konstytucji z 1997 r., Kraków 1998.

Słomka T., Między dwiema konstytucjami: kilka uwag o specyfice polskiej ciagłości $i$ zmiany systemowej, [in:] A. Materska-Sosnowska and T. Słomka (eds.), Konstytucje polskie z 1952 i 1997 roku: tradycja, instytucje, praktyka ustrojowa, Warsaw 2015.

Słomka T., Prezydent Rzeczypospolitej po 1989 roku. Ujęcie porównawcze, Warsaw 2005.

Słomka T., Stan demokracji konstytucyjnej $w$ Polsce na tle modelu transformacji systemowej, [in:] T. Słomka (ed.), Demokracja konstytucyjna w Polsce, Warsaw 2019.

Sokolewicz W., Konstytucja wobec ewolucyjnej zmiany ustroju: od dyktatury proletariatu do demokracji parlamentarnej, Studia Konstytucyjne, vol. VIII, Warsaw 1990.

Sokolewicz W., Rozdzielone, lecz czy równe? Legislatywa i egzekutywa w Małej Konstytucji 1992 roku, «Przegląd Sejmowy»1993, no. 1.

Tomaszewski W., Kompromis polityczny $w$ procesie stanowienia Konstytucji Rzeczypospolitej z kwietnia 1997 roku, Pułtusk 2007.

Trembicka K., Okragły Stót w Polsce. Studium o porozumieniu politycznym, Lublin 2003.

Winczorek P., Uwarunkowania prac nad nowa Konstytucja Rzeczypospolitej Polskiej, «Państwo i Prawo» 1997, no. 11-12. 